GENOME METHODS

\title{
A Simple and Efficient Method for Making Site-directed Mutants, Deletions, and Fusions of Large DNA Such as P1 and BAC Clones
}

\author{
Jan Borén, ${ }^{1,2,5}$ Isabelle Lee, ${ }^{1}$ Matthew J. Callow, ${ }^{4}$ Edward M. Rubin, ${ }^{4}$ \\ and Thomas L. Innerarity ${ }^{1,2,3}$
}

${ }^{1}$ Gladstone Institute of Cardiovascular Disease, ${ }^{2}$ Cardiovascular Research Institute, and ${ }^{3}$ Department of Pathology, University of California, San Francisco, California 94141-9100; ${ }^{4}$ Life Sciences Division, Lawrence Berkeley Laboratory, University of California, Berkeley, California 94720

This study addresses two important technical problems: how to perform targeted alterations such as site-directed mutagenesis and deletions in large fragments of DNA and how to construct full-length genes from two partly overlapping bacterial artificial chromosome (BAC) plasmids. Given the size and the lack of convenient unique restriction sites in these large-insert bacterial clones, these are nontrivial tasks. Here we describe a simple and efficient protocol based on RecA-assisted restriction endonuclease (RARE) cleavage, a method that enables sequence-specific cleavage of genomic DNA. The same protocol has been used with minor modifications to introduce site-specific mutations into an apolipoprotein-B 90-kb PI clone, to generate deletions in a 160-kb BAC, and to generate a 160-kb BAC containing the complete 92-kb gene for low-density lipoprotein-related protein-1 (LRP-1) from two smaller overlapping BACs (“BAC marriage”).

RecA-assisted restriction endonuclease (RARE) cleavage consists of protecting a specific restriction endonuclease site with a complementary oligonucleotide. In the presence of RecA, a triplex DNA complex is formed that prevents methylation at the protected sites (Ferrin and CameriniOtero 1991; Ferrin 1995) while unprotected sites are methylated by the corresponding methylase. After dissociation of the complex, the protected sites can be cleaved with the specific restriction endonuclease. Previously, a RARE cleavage strategy was used to introduce specific mutations into a large DNA fragment (Callow et al. 1994). This procedure permitted the selective removal, sitedirected mutagenesis, and reinsertion of small DNA fragments into the large DNA.

RARE cleavage techniques have been used to introduce mutations into a $90-\mathrm{kb}$ apolipoprotein-B (apo-B) P1 plasmid clone (Callow and Rubin 1995). Both positive and negative selection markers were necessary because of the large number of rearranged clones. We report here a significant improvement of the original technique (Callow and Rubin 1995). In our revised protocol, the

\footnotetext{
${ }^{5}$ Corresponding author.

E-MAIL jan_boren.gicd@quickmail.ucsf.edu; FAX (415) 285 5632.
}

vast majority of the isolated P1 plasmids are correct, and therefore neither colony hybridization nor positive selection markers are required to screen for deleted or mutated clones. An added benefit of this simplification is that the sitedirected mutagenesis of a P1 clone can be completed in $\sim 2$ weeks. This protocol has been used not only for site-directed mutagenesis but also, with minor modifications, to create a specific deletion in a $160-\mathrm{kb}$ bacterial artificial chromosome (BAC) and to generate a chimeric 160-kb BAC containing the complete $92-\mathrm{kb}$ gene for low density lipoprotein-related protein-1 (LRP-1) from two smaller overlapping BACs ("BAC marriage").

The simplicity and reproducibility of this protocol make it a valuable tool for site-directed mutagenesis in large-insert bacterial clones, for construction of large genes, and for mapping genetic elements on large constructs.

\section{RESULTS}

\section{Site-specific Mutagenesis of a 90-kb Pl Clone}

RARE cleavage of a 5.5-kb EcoRI fragment from the apo-B P1 plasmid p158 was performed as shown in Figure 1. Oligonucleotides 1 and 2, 


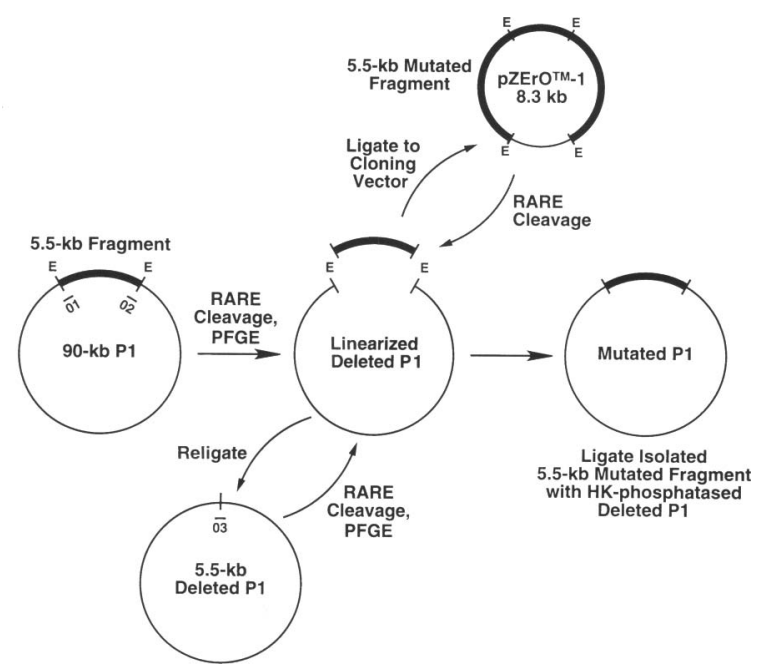

Figure 1 Schematic of the method for introducing mutations in a P1 plasmid. 01, 02, and 03 are 60 -mer oligonucleotides complementary to the sequence surrounding the centrally positioned EcoRI.

which are complementary to two EcoRI sites in the apo-B gene, were used to protect these sites against subsequent methylation with EcoRI methylase. After EcoRI digestion, the 5.5-kb deleted P1 plasmid and the 5.5-kb fragment were isolated by pulsed-field gel electrophoresis (PFGE) and treated with Gelase. A total of $4 \mu \mathrm{g}$ of EcoRI-digested P1 plasmid was loaded onto a $1 \%$ low-melt agarose preparative gel to separate the 5.5-kb deleted P1 DNA from linearized P1 DNA and nonspecific cleavage fragments. The $5.5-\mathrm{kb}$ fragment was isolated from the lower part of the gel (Fig. 2).

The $5.5-\mathrm{kb}$ fragment was cloned into the $\mathrm{pZ}$ ErO-1 vector (Invitrogen) and subjected to sitespecific mutagenesis to generate 10 different mutants. The $5.5-\mathrm{kb}$ mutated fragment was cloned back into a linearized P1 plasmid with the $5.5-\mathrm{kb}$ fragment deleted. Instead of simply excising the 5.5-kb fragment from a wild-type P1 clone and inserting the mutated $5.5-\mathrm{kb}$ DNA fragment, we elected to use a P1 plasmid lacking the $5.5-\mathrm{kb}$ fragment because the efficiency of RARE cleavage is higher when only one oligonucleotide is needed (for the $5.5-\mathrm{kb}$ deleted P1 plasmid), whereas two different oligonucleotides are required for the wild-type P1 plasmid. RARE cleavage with two oligonucleotides often generates both linearized and deleted P1 DNA and, as shown in Figure 2, the deleted P1 DNA migrates close to the full-length linearized P1 DNA, mak-

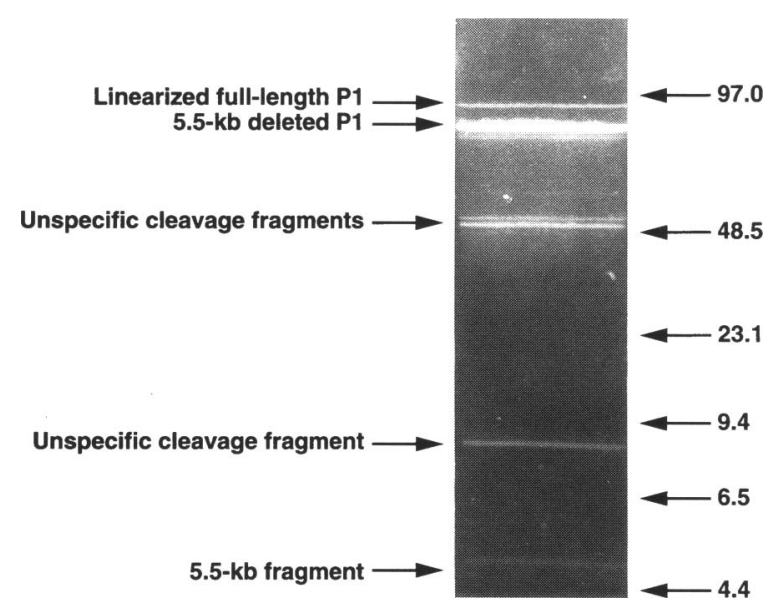

Figure 2 Purification of P1 DNA by pulsed-field gel electrophoresis. After RARE cleavage, the EcoRIdigested P1 plasmid was electrophoresed on a $1 \%$ low-melt agarose pulsed-field gel. A portion of the gel was stained with ethidium bromide. The migration of a low-range PFGE marker (New England Biolabs) is shown as numbers in kilobases.

ing it difficult to separate them by preparative PFGE.

The linearized deleted P1 plasmid was religated and electroporated into DH10B cells. Positive clones were selected on kanamycin plates, and plasmids were screened by miniprep as described by Shizuya et al. (1992). Of 20 P1 plasmids, 16 appeared normal by EcoRI, HindIII, EcoRV, SalI, and HpaI restriction digestion. The positive $\mathrm{P} 1$ plasmids were sequenced over the deleted region and found to be correct (Fig. 3). Our protocol for direct sequencing of large DNA routinely gives us good sequences for both P1 and BAC DNA. The use of DH10B cells made it possible to routinely obtain a high yield of P1 DNA, thus making minipreps and direct sequencing of P1 DNA possible.

After RARE cleavage of the deleted P1 with oligomer 3 (complementary to the newly formed EcoRI site) (Fig. 1), the linearized DNA was treated with phosphatase and purified by PFGE. The mutated 5.5 -kb fragment was isolated by RARE cleavage with oligomers 1 and 2 (Fig. 1). In this case, the 60-base oligomers protected against methylation, although they were complementary to only 30 bases on one half of the RARE cleavage site. RARE cleavage was used to isolate the $5.5-\mathrm{kb}$ fragment from the cloning vector because the fragment contains several internal EcoRI sites. If the isolated fragment had contained only one 

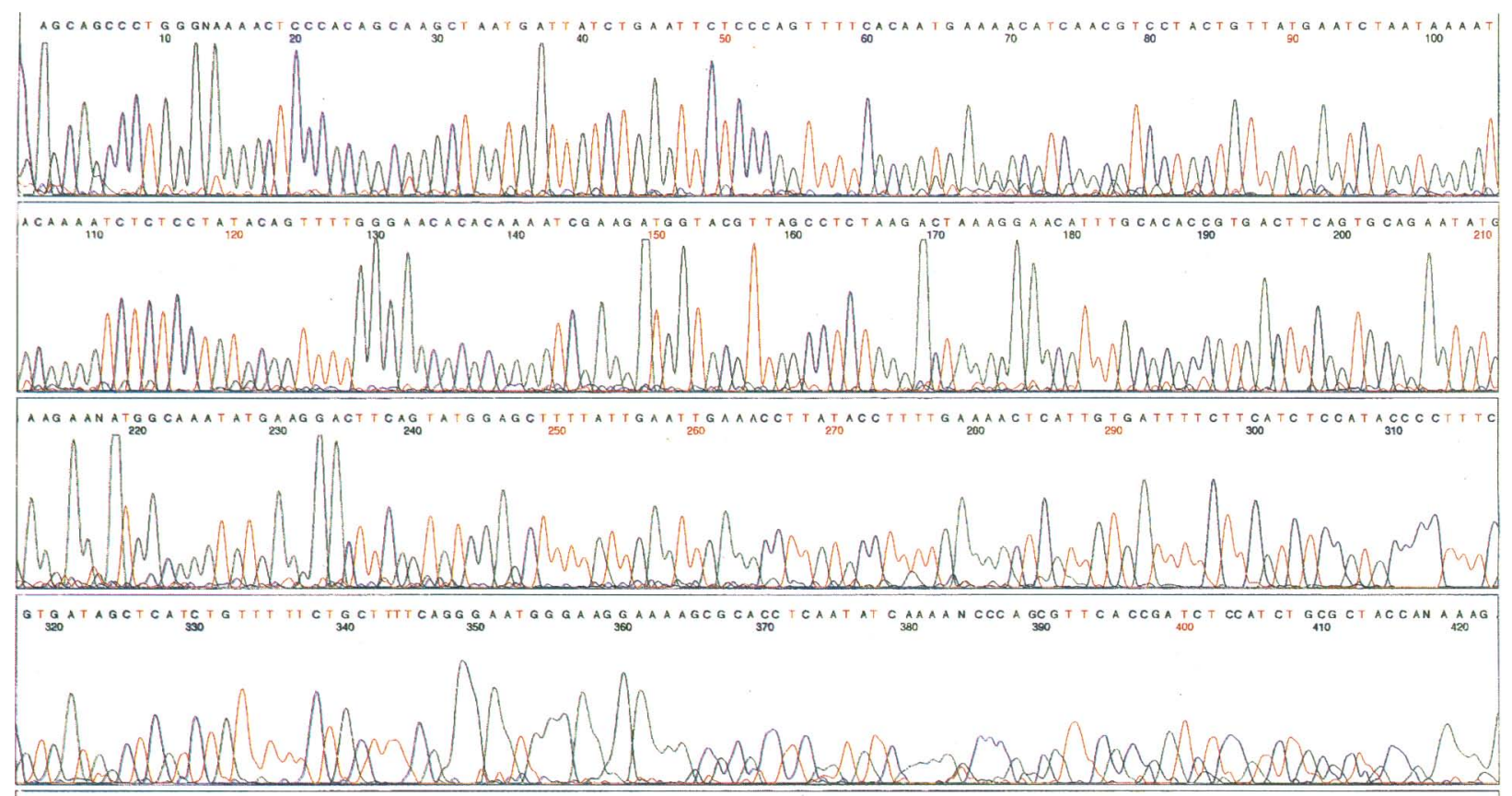

Figure 3 Direct automatic sequencing of 85-kb P1 DNA. The electropherogram is shown from sequencing over the EcoRl site formed after removal of the $5.5-\mathrm{kb}$ fragment from the apo-B P1 plasmid.

EcoRI site at each end of the fragment, it could have been isolated by simple EcoRI digestion instead of RARE cleavage.

The linearized, phosphatased, Gelase-treated vector was ligated to the $5.5-\mathrm{kb}$ fragment. Several ligations were performed with a dilution series of the mutated $5.5-\mathrm{kb}$ fragment. To avoid integrating multiple inserts into the P1 clone, we used the lowest concentration of the $5.5-\mathrm{kb}$ fragment in the ligation mixture that resulted in colonies. Plasmids were screened by minipreps and digested with EcoRI, HindIII, HpaI, and EcoRV (Fig. 4). This strategy has been used for 10 different constructs, and 158 colonies have been analyzed; 135 of these colonies (85\%) contained the desired P1 clone and were not rearranged. We have obtained similar results using $A l u \mathrm{I}$ methylase/ HindIII endonuclease for RARE cleavage of P1 clones. For optimal performance, however, AluI methylase requires a 60 -min incubation instead of the 30-min incubation for EcoRI methylase.

\section{Creating a 160-kb BAC from Two Smaller Overlapping BACs (BAC Marriage)}

Our protocol also has been used to create a 160$\mathrm{kb}$ BAC containing the whole $92-\mathrm{kb}$ gene of LRP-1 from two smaller, overlapping BACs. A hu- man BAC library (Genome System) was screened with one $5^{\prime}$ and one $3^{\prime}$ PCR replicon, and four BACs containing the $5^{\prime}$ sequence and two BACs

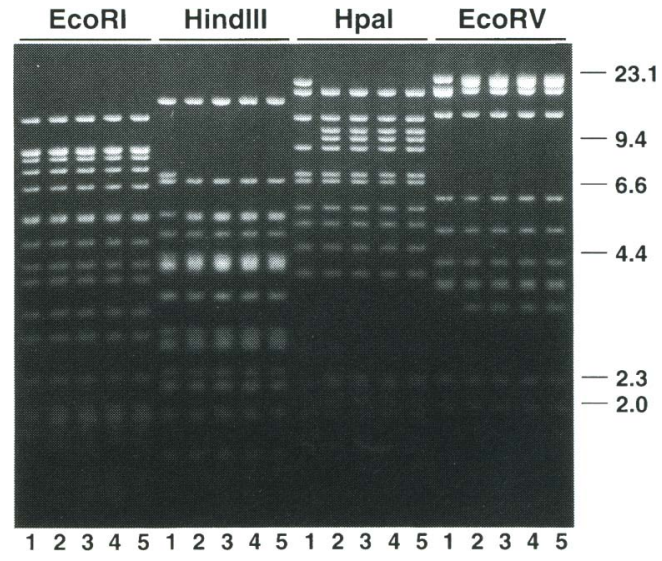

Figure 4 Restriction endonuclease analysis of P1 minipreps. DNA from four different colonies was analyzed by restriction endonuclease digestion with EcoRI, HindIII, Hpal, and EcoRV and electrophoresed on a $0.8 \%$ agarose gel for $12 \mathrm{hr}$ at $10 \mathrm{~V}$. (Lane 1) The 5.5-kb deleted P1; (lanes 2-4) mutated 5.5-kb fragments reinserted into the $5.5-\mathrm{kb}$ deleted $\mathrm{P} 1$. EcoRI digests of the deleted $\mathrm{P} 1$ with the $5.5-\mathrm{kb}$ fragment reinserted do not show a $5.5-\mathrm{kb}$ fragment because the fragment contains several internal EcoRI sites. 


\section{BORÉN ET AL.}

containing the $3^{\prime}$ sequence of LRP-1 were identified. Because no BAC clone contained the complete gene, we used RARE cleavage to generate a $160-\mathrm{kb}$ BAC containing the full-length gene from two partly overlapping plasmids (Fig. 5).

Two 60-mer oligonucleotides, EcoRI-1 and EcoRI-2, were used. EcoRI-1 is homologous to the 30 nucleotides on both sides of the EcoRI site at nucleotide 1206 in the BAC vector pBelo11. This site is present in the middle of the chloramphenicol-resistance gene. EcoRI-2 is homologous to an EcoRI site in exon 35 . The BAC containing the $5^{\prime}$ sequence of LRP-1 was subjected to RARE cleavage with oligonucleotides 1 and 2, and the fragments were isolated with PFGE. From the exon map of Van Leuven et al. (1994), it was clear that a 62 -kb fragment contained the $5^{\prime}$ sequence fragment of the gene, because the other fragment was too small. The RARE cleavage was repeated with a BAC containing the 3 ' sequence of LRP-1, and Southern analysis showed that the $3^{\prime}$ sequence of LRP-1 was present on a 98-kb fragment (data not shown). The 62 - and $98-\mathrm{kb}$ fragments were isolated by PFGE (Fig. 6), treated with Gelase, ligated, and electrotransformed into DH10B cells.

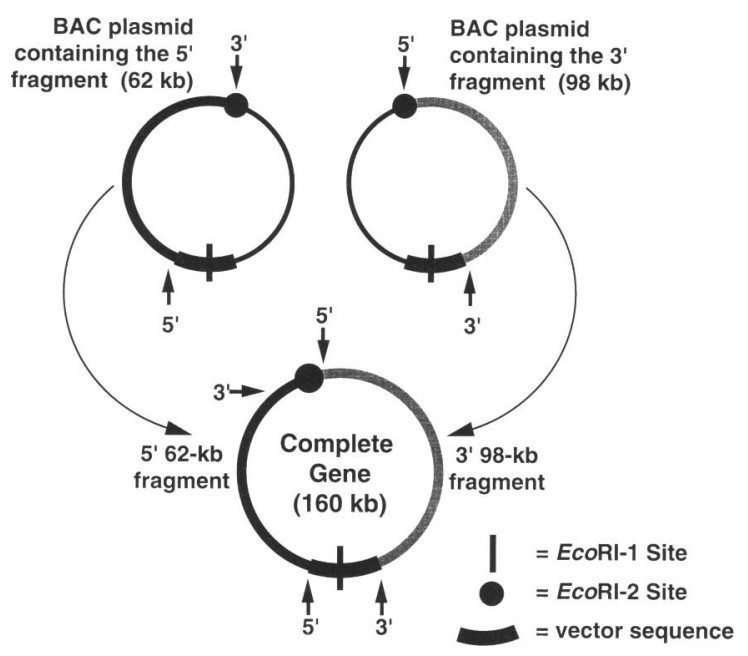

Figure 5 Schematic of the method for creating a chimeric BAC. EcoRI-1 and EcoRI-2 are 60-mer oligonucleotides complementary to the sequence surrounding the centrally positioned EcoRl site. Two DNA fragments (a 62-kb fragment containing the promotor sequence and exon 1 to the EcoRI site in exon 35 and a 98-kb fragment containing the sequence from the EcoRI site in exon 35 to exon 89) were isolated from two overlapping BACs by RARE cleavage followed by PFGE and were religated after Gelase treatment. The resulting $160-\mathrm{kb}$ BAC contains the full-length 92-kb LRP-1 gene.

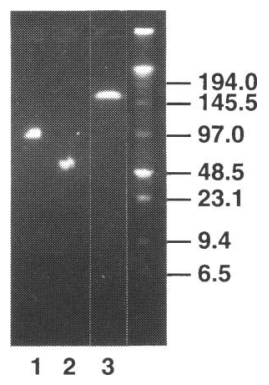

Figure 6 Isolated DNA fragments containing the $5^{\prime}$ and the $3^{\prime}$ sequences of LRP-1. (Lane 1) Isolated $98-\mathrm{kb}$ fragment containing the sequence from the EcoRl site in exon 35 to exon 89 of LRP-1; (lane 2) isolated $62-\mathrm{kb}$ fragment containing the promotor sequence and exon 1 to the EcoRI site in exon 35 of LRP-1; (lane 3) full-length 160-kb BAC linearized with lambda terminase. The migration of a lowrange PFGE marker (New England Biolabs) is shown as numbers in kilobases.

Five colonies were selected on chloramphenicol plates and screened by polymerase chain reaction (PCR). One of these colonies contained both the $5^{\prime}$ and the 3' sequences of the gene (Fig. 7). Analysis of this colony showed that it contained a full-length 160 -kb fragment (Fig. 6). RARE mapping of the gene with oligonucleotides homologous to sequences in exons 35,46 , and 89 in the LRP-1 gene, and at nucleotide 1206 in the BAC

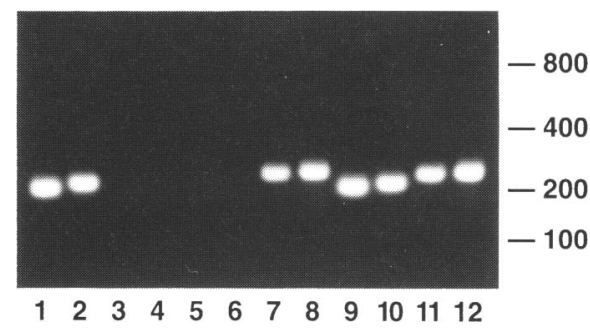

Figure 7 PCR analysis of the overlapping $B A C$ clones and the resulting 160-kb BAC containing the full-length LRP-1 gene. The " 5 '-LRP-1 BAC" was analyzed in lanes $1-4$, the " 3 '-LRP-1 BAC" in lanes 5-8, and the 160-kb full-length BAC in lanes 9-12. Two different PCR replicons were analyzed from the 5 ' sequence of the LRP-1 gene. The first is present in the LRP promotor (lanes 1,5,9), and the second in the $5^{\prime}$ sequence of exon 1 (lanes 2,6,10). Two different PCR replicons were analyzed from the 3 ' sequence of the LRP-1 gene. The first is present in the $5^{\prime}$ sequence of exon 89 (lanes $3,7,11$ ), and the second in the most $3^{\prime}$ sequence of exon 89 (lanes $4,8,12)$. The migration of a low DNA mass ladder (Gibco-BRL) is shown as numbers in base pairs. 
vector pBelo11, resulted in fragments with the length expected from the exon mapping described by Van Leuven et al. (1994). Furthermore, extensive fingerprinting of the new clone and the two starting clones with EcoRI, HindIII, HpaI, and EcoRV did not reveal any deletions or rearrangement (data not shown). Finally, the $160-\mathrm{kb}$ fulllength BAC was sequenced over the EcoRI site in exon 35 that was formed after the ligation on the two BACs, in the $5^{\prime}$ promotor sequence, and in exon 89 and was found to be correct.

\section{Creating Deletions in a 160-kb BAC}

This protocol also can be used to delete fragments from vectors larger than P1 plasmids and has been used successfully to delete a 10.2-kb fragment from the chimeric 160-kb BAC containing the full-length LRP-1 gene. After RARE cleavage with oligonucleotides homologous to EcoRI sequences in exons 35 and 46, the deleted $160-\mathrm{kb}$ BAC was isolated with PFGE, treated with Gelase, religated, and electrotransformed into electrocompetent DH10B cells. Positive clones were selected on chloramphenicol plates, and plasmids were screened by minipreps as described by Shizuya et al. (1992). Of seven colonies, three appeared normal by EcoRI, HindIII, HpaI, EcoRV, NotI, and Sall restriction digestion.

\section{DISCUSSION}

Cloning large pieces of DNA is usually hampered by a lack of convenient and unique restriction sites. To overcome this problem, we developed a protocol based on the RARE cleavage technique to perform targeted alterations such as sitedirected mutagenesis and deletions in large fragments of DNA and to construct full-length genes from two partly overlapping BAC plasmids.

The major difference between this protocol and an earlier RARE-based protocol (Callow et al. 1994 ) is that this is a one-step procedure in which the mutated fragment is directly ligated back into the P1 plasmid, whereas the older two-step method uses both positive and negative selection markers to reinsert the mutated fragment. This simplification could be accomplished by isolating the correct cleavage products by PFGE before ligation and by avoiding precipitation of the DNA in any step and using instead spot dialysis on Millipore filters. These modifications are the keys to the low frequency of rearrangements and unwanted deletions we observed in the modified procedure. In our hands, we routinely obtain $\sim 85 \%$ correctly mutated P1 plasmids within $2-3$ weeks, compared with less than $1 \%$ with the older, more complicated protocol (Callow et al. 1994).

To reinsert the $5.5-\mathrm{kb}$ fragment, we chose to generate a religated, deleted P1 plasmid. We did this because we planned to generate 10 different lines of transgenic mice with different mutations in the same $5.5-\mathrm{kb}$ fragment; thus we planned to insert the same $5.5-\mathrm{kb}$ fragment into the P1 plasmid 10 times. RARE cleavage sometimes cuts DNA at only one of two unprotected sites, and it can be hard to separate single-cleaved, linearized, full-length 90-kb DNA from double-cleaved 85kb DNA by preparative PFGE (see Fig. 2). We wanted to avoid the possibility of inserting the $5.5-\mathrm{kb}$ fragment into a full-length linearized P1 plasmid instead of a deleted P1 plasmid. Using this strategy, we successfully generated 10 transgenic lines, and all the constructs have expressed recombinant LDL containing apo-B with the desired mutations. When it is possible to cleanly isolate DNA with a fragment deleted from linearized DNA, a more streamlined protocol skipping the religation of the fragment-deleted DNA should be possible. However, the religation of DNA fragments even larger than P1 plasmids can be performed with minor effort. We used this technique to create a deletion in a 160-kb BAC.

The RARE technique was also used to construct a full-length LRP-1 gene. The LRP-1 gene contains in intron 44 a long and complex repetitive sequence motif that has caused a major cloning problem. This intron appeared to be refractive to cloning: It was not present in three independent human genomic lambda libraries, two genomic cosmid libraries, two yeast artificial chromosome (YAC) libraries, or a bacteriophage P1 library (Van Leuven et al. 1994). Because we could not find a BAC containing the complete gene, we used RARE cleavage to generate a $160-\mathrm{kb}$ $\mathrm{BAC}$ containing the full-length gene from two partly overlapping plasmids (Fig. 5). For RARE cleavage, we could use one of two different EcoRI sites in the BAC vector pBelo11. We chose the EcoRI site located at nucleotide 1206 in the pBelo11 vector because this site is present in the middle of the chloramphenicol-resistance gene. Thus, only colonies with the two fragments in the proper orientation after ligation would grow on the chloramphenicol plates. The resulting $160-\mathrm{kb}$ BAC contains both the $5^{\prime}$ and the $3^{\prime}$ sequences of the LRP-1 gene, and extensive map- 


\section{BORÉN ET AL.}

ping has not revealed any deletions or rearrangements in the resulting BAC. However, the final proof that the construct is correct will be the expression of functional LRP-1 in transgenic mice.

Another excellent approach to introducing small insertions, deletions, or point mutations in large DNA is the YAC gene-targeting approach (McCormick et al. 1995, 1996; Peterson et al. 1995). This technique exploits the efficient homologous recombination in yeast to introduce mutations. However, the YAC-based technique is more labor-intensive because the yield of pure YAC DNA is only a small fraction of the amount of the P1 DNA that can be obtained from bacteria (McCormick et al. 1994), and the protocol uses a two-step "pop-in, pop-out" strategy (McCormick et al. 1995, 1996). Furthermore, the efficient machinery for homologous recombination in the yeast can, unfortunately, give rise to spontaneous rearrangement of the DNA. This most likely explains why the long complex repetitive sequence in intron 44 of the LRP-1 gene could not be found in any YAC library and why it was described as "unstable and unclonable in yeast" (Van Leuven et al. 1994). An advantage of the YAC-based technique is that restriction sites relatively close to the region of interest are not necessary. However, because both HindIII and EcoRI can be used with the RARE-based procedure and the average fragments generated by these endonucleases in the human genome are $4-5 \mathrm{~kb}$ long, it is likely that one or both of these sites will be available. Thus, when EcoRI or HindIII sites are present $\sim 5-10 \mathrm{~kb}$ from the region of interest and when the DNA sequences around these restriction sites are known, RARE cleavage offers many advantages. Furthermore, RARE cleavage can be performed also if the sequence is known for only 30 bases on one half of the RARE cleavage site. This will generate more unspecific cleavage products, but this problem can be overcome because the DNA fragment of interest is isolated by PFGE.

We have shown that this protocol can be used to introduce site-specific mutations into a 90-kb P1 clone, to generate deletions in a $160-\mathrm{kb}$ BAC clone, and to create a $160-\mathrm{kb}$ BAC from two smaller, partly overlapping BACs (BAC marriage). The simplicity and reproducibility of this protocol make it a valuable tool for site-directed mutagenesis for construction of large genes, for mapping genetic elements on large constructs, and for other applications where "cutting and ligating" large DNAs such as P1 and BACs are necessary.

\section{METHODS}

\section{Preparation of PI and BACDNA}

The 90-kb apo-B P1 plasmid p158 (Linton et al. 1993) and BAC plasmids were prepared essentially as described by McCormick et al. (1994). Escherichia coli strain DH10B (Gibco BRL) harboring the P1 or BAC plasmids was grown in LB medium containing $25 \mu \mathrm{g} / \mathrm{ml}$ kanamycin (for P1) or $12.5 \mu \mathrm{g} / \mathrm{ml}$ chloramphenicol (for BAC). For large preparations, 1 liter of medium was inoculated with $10 \mathrm{ml}$ of an overnight culture and placed in a shaking incubator at $37^{\circ} \mathrm{C}$. The bacteria were then routinely grown for $7 \mathrm{hr}$ (BAC), or isopropyl- $\beta$-D-thiogalactopyranoside (final concentration $1 \mathrm{~mm}$ ) was added to the culture after $1 \mathrm{hr}$ (for $\mathrm{P} 1$ ), and the bacteria were grown for additional $4 \mathrm{hr}$ (for $\mathrm{P} 1)$. The P1 and BAC DNAs were prepared by alkaline lysis with the Qiagen Plasmid Maxi Kit (Qiagen), according to the manufacturer's instructions. The P1 or BAC DNA was purified on three Qiagen-tip 500 columns, using the washing and elution buffers contained in the kit except for buffer P2, which was prepared freshly before use. The purified P1 and BAC plasmids were extracted with phenol/ chloroform and precipitated with isopropanol. The concentration of the DNA was assessed by spectrophotometry, after solubilization of the DNA in $300 \mu$ l of TE-buffer (10 mM Tris- $\mathrm{HCl}$ at $\mathrm{pH} 7.4,1 \mathrm{~mm}$ EDTA). Care should be taken during the whole procedure to avoid overdrying pellets or vortexing at any step during the whole procedure. From a 1 liter culture, the typical yield was $600-800 \mu \mathrm{g}$ of P1 DNA and $150-200 \mu \mathrm{g}$ of BAC DNA. The DNA was stored at $4^{\circ} \mathrm{C}$ and used as is for direct DNA sequencing or RARE cleavage.

\section{RARE Cleavage of PI DNA}

RARE cleavage was performed essentially as described by Ferrin (1995) with several modifications (Fig. 1). To a 1.5$\mathrm{ml}$ centrifuge tube the following solutions were added in order: $\mathrm{H}_{2} \mathrm{O}$ to achieve a final volume of $160 \mu \mathrm{l}, 32 \mu \mathrm{l}$ of RARE buffer $(125 \mathrm{~mm}$ Tris-acetate at $\mathrm{pH} 7.85,20 \mathrm{~mm}$ $\mathrm{MgCl}_{2}, 2.5 \mathrm{~mm}$ spermidine hydrochloride, $2 \mathrm{~mm}$ DTT), 40 $\mu \mathrm{g}(\cong 2.0 \mathrm{mg} / \mathrm{ml})$ of RecA protein (USB), $16 \mu \mathrm{l}$ of ADP/ ATP $\gamma \mathrm{S}(11 \mathrm{mM}$ ADP, $3 \mathrm{~mm}$ ATP $\gamma \mathrm{S}), 0.38 \mu \mathrm{g}(0.16 \mu \mathrm{g} / \mu \mathrm{l})$ each of the two 60-mer oligomers 1 and 2 (Fig. 1) (or 0.72 $\mu \mathrm{g}$ of oligomer 3 if the RARE cleavage is performed with only one oligomer to linearize the P1 plasmid), $4 \mu \mathrm{g}$ of DNA, and $8 \mu \mathrm{l}$ of acetylated bovine serum albumin $(2 \mathrm{mg} /$ $\mathrm{ml}$ ). After a 10 -min incubation at $37^{\circ} \mathrm{C}$ to allow formation of a triplex DNA complex, $8 \mu \mathrm{l}$ of EcoRI-methylase (32 units freshly diluted in water) (New England Biolabs) and $8 \mu$ of $S$-adenosylmethionine $(2.4 \mathrm{~mm}$ freshly diluted in water) were added to methylate all unprotected EcoRI sites, and the mixture was incubated at $37^{\circ} \mathrm{C}$ for $30 \mathrm{~min}$. The methylase was heat-inactivated at $65^{\circ} \mathrm{C}$ for $15 \mathrm{~min}$, and the P1 plasmid was spot-dialyzed for $30 \mathrm{~min}$ on a $25-\mathrm{mm}$ filter (Millipore VSWPO 2500) against $50 \mathrm{ml}$ of $0.5 \times$ TE buffer and subsequently digested in the buffer provided by the manufacturer with 80 units of EcoRI restriction endonuclease enzyme (New England Biolabs) for $60 \mathrm{~min}$.

\section{Preparative PFGE}

A total of $4 \mu \mathrm{g}$ of EcoRI-digested P1 plasmid (in a total volume of $200 \mu \mathrm{l}$ ) was loaded onto a $1 \%$ low-melt agarose 
preparative gel (Bio-Rad), and PFGE was performed for 12 hr using a linear ramp from 2 to $6 \mathrm{sec}$ with $6 \mathrm{~V} / \mathrm{cm}$ in $0.5 \times$ TAE buffer at $14^{\circ} \mathrm{C}$. After PFGE, $1.0-\mathrm{cm}$ sections from each side of the preparative gel were stained with ethidium bromide to visualize the $5.5-\mathrm{kb}$ fragment, and the P1 DNA with the $5.5-\mathrm{kb}$ deletion. Agarose strips $(\sim 0.2 \mathrm{~g}$ each $)$ containing the $5.5-\mathrm{kb}$ deleted P1 DNA and the $5.5-\mathrm{kb}$ fragment were excised from the unstained portion of the gel and equilibrated for $30 \mathrm{~min}$ at room temperature in $25 \mathrm{ml}$ of Gelase buffer (Epicentre Technologies) supplemented with $30 \mathrm{~mm} \mathrm{NaCl}$. The agarose $(-100-200 \mu \mathrm{l})$ was melted at $68^{\circ} \mathrm{C}$ for $10 \mathrm{~min}$, equilibrated at $45^{\circ} \mathrm{C}$ for $10 \mathrm{~min}$, and digested with 1 unit of Gelase for $60 \mathrm{~min}$.

\section{Site-specific Mutagenesis of a $5.5-\mathrm{kb}$ DNA Fragment}

The isolated 5.5-kb fragment was cloned into the pZErO-1 vector (Invitrogen) and subjected to site-specific mutagenesis with the Morph System (5 Prime $\rightarrow 3$ Prime, Inc.) to introduce stop codons and one- or two-nucleotide substitutions or with the ExSite PCR System (Stratagene) to introduce more complex modifications.

\section{Intramolecular Ligation of Truncated P1 and BAC Plasmids}

A 100- $\mu$ l aliquot of the Gelase-treated agarose strip from the preparative PFGE gel was mixed gently with $11 \mu$ of $10 \times$ ligation buffer (New England Biolabs) and 200 units of T4 DNA ligase (New England Biolabs) and incubated for $16 \mathrm{hr}$ at $15^{\circ} \mathrm{C}$.

\section{Intermolecular Ligation of a P1 Plasmid and a 5.5-kb DNA Fragment}

The religated P1 plasmid with the 5.5-kb deletion was used to reinsert the mutated $5.5-\mathrm{kb}$ fragment into the P1 plasmid. After RARE cleavage of $4 \mu \mathrm{g}$ of the deleted P1 with oligomer 3 (complementary to the newly formed EcoRI site) (Fig. 1), the linearized DNA (in a total volume of 200 $\mu 1)$ was treated with 40 units of HK Phosphatase as recommended by the manufacturer (Epicentre Technologies) and purified by PFGE as described above. After treatment with phosphatase and Gelase, the vector was recovered from the preparative PFGE in a total volume of $200 \mu \mathrm{l}$.

The mutated $5.5-\mathrm{kb}$ fragment was isolated by RARE cleavage as described above with oligomers 1 and 2 (Fig. 1). In this case, the 60-base oligomers were complementary with only 30 bases on one half of the duplex sequence, but this was sufficient to protect against methylation. After EcoRI digestion, one-fourth of the reaction volume (corresponding to $1 \mathrm{mg}$ of DNA) was subjected to $0.8 \%$ agarose preparative gel electrophoresis. The $5.5-\mathrm{kb}$ fragment was recovered from the agarose gel with QIAquick Gel Extraction Kit (Qiagen) and resuspended in $50 \mu \mathrm{l}$ of $10 \mathrm{~mm}$ Tris$\mathrm{HCl}$ at $\mathrm{pH} 7.4$.

Several ligations were performed with a dilution series of the mutated $5.5-\mathrm{kb}$ fragment to avoid integration of multiple inserts into the P1 clone. Twenty-microliter ali- quots of the linearized, phosphatased, deleted P1 vector were mixed with $5,1,0.5,0.1,0.05$, or $0.01 \mu \mathrm{l}$ of the isolated mutated $5.5-\mathrm{kb}$ DNA fragment, $3 \mu \mathrm{l}$ of $10 \times$ ligation buffer (New England Biolabs), and 300 units of T4 DNA ligase (New England Biolabs) in a total volume of 30 $\mu \mathrm{l}$ and incubated for $16 \mathrm{hr}$ at $15^{\circ} \mathrm{C}$. Colonies were picked from the plate in which the lowest concentration of the 5.5 - $\mathrm{kb}$ fragment in the ligation mixture resulted in colonies.

\section{RARE Cleavage of Two BACs}

Two BACs containing the $5^{\prime}$ or the $3^{\prime}$ sequence of the LRP-1 gene were subjected to RARE cleavage as described above with two 60-mer oligonucleotides, EcoRI-1 and EcoRI-2. EcoRI-1 is homologous to the 30 nucleotides on both sides of the EcoRI site at nucleotide 1206 in the BAC vector pBelo11. This site is present in the middle of the chloramphenicol-resistance gene. EcoRI-2 is homologous to an EcoRI site in exon 35. A 62-kb and a 98-kb DNA fragment were isolated by preparative PFGE and treated with Gelase in a volume of $200 \mu \mathrm{l}$ as described above.

\section{Intermolecular Ligation of Two Deleted BACs (BAC Marriage)}

Aliquots ( $90 \mu \mathrm{l}$ each) of the $62-\mathrm{kb}$ and the $98-\mathrm{kb}$ fragments were mixed with $20 \mu \mathrm{l}$ of $10 \times$ ligation buffer (New England Biolabs) and 300 units of T4 DNA ligase (New England Biolabs) and ligated at $15^{\circ} \mathrm{C}$ for $16 \mathrm{hr}$ in a reaction volume of $200 \mu \mathrm{l}$.

\section{Electroporation}

The ligation mixture was spot-dialyzed for $30 \mathrm{~min}$ on a $25-\mathrm{mm}$ filter (Millipore VSWPO 2500) against $50 \mathrm{ml}$ of $0.5 \times \mathrm{TE}$ buffer, and $12.5 \mu \mathrm{l}$ of the ligation mixture was used to transform $50 \mu \mathrm{l}$ of electrocompetent DH10B cells with an E. coli pulser apparatus (Bio-Rad) at $1.6 \mathrm{kV}$ in 0.1 $\mathrm{cm}$ cuvettes according to the manufacturer's instructions. Aliquots of the transformed cells $(200 \mu \mathrm{l})$ were plated on $100-\mathrm{mm} \mathrm{LB}$ plates containing $25 \mu \mathrm{g} / \mathrm{ml}$ of kanamycin (for P1) or $12.5 \mu \mathrm{g} / \mathrm{ml}$ of chloramphenicol (for BAC) and subsequently incubated at $37^{\circ} \mathrm{C}$ overnight. We routinely obtain 1000-1500 colonies on each LB plate.

\section{P1 and BAC Miniprep Protocol}

Minipreps of P1 or BAC plasmids were performed with the modified alkaline lysis method of Shizuya et al. (1992). Routinely, $5 \mathrm{ml}$ of LB medium containing $25 \mu \mathrm{g} / \mathrm{ml}$ of kanamycin (for P1 plasmids) or $12.5 \mu \mathrm{g} / \mathrm{ml}$ of chloramphenicol (for BAC plasmids) was inoculated with a single bacterial colony and incubated at $37^{\circ} \mathrm{C}$ overnight with vigorous shaking. The cells were concentrated in a $2.0-\mathrm{ml}$ microcentrifuge tube (Eppendorf) and resuspended in 100 $\mu \mathrm{l}$ of an ice-cold solution of $50 \mathrm{~mm}$ glucose, $10 \mathrm{~mm}$ EDTA, and $25 \mathrm{~mm}$ Tris- $\mathrm{HCl}$ at $\mathrm{pH} 8.0$. The tubes were placed on ice, and $200 \mu \mathrm{l}$ freshly prepared lysis buffer was added $(0.2$ $\mathrm{M} \mathrm{NaOH}, 1 \%$ SDS). The tubes were inverted carefully five times, and $150 \mu \mathrm{l}$ of ice-cold potassium acetate $(\mathrm{pH} 4.8)$ was added. The tubes were again inverted five times and subsequently centrifuged for $5 \mathrm{~min}$ at full speed in an mi- 


\section{BORÉN EI AL.}

crofuge at room temperature. The supernatant was transferred to a fresh tube, and two volumes of cold $100 \%$ ethanol were added, followed by a 5-min centrifugation. The pellet was rinsed with $500 \mu \mathrm{l}$ of $70 \%$ ethanol and dried briefly at room temperature for $10 \mathrm{~min}$. The pellet was resuspended gently in $40 \mu \mathrm{l}$ of TE buffer containing DNase-free pancreatic RNase $(20 \mu \mathrm{g} / \mathrm{ml})$. For restriction digestion with EcoRI, HindIII, HpaI, and EcoRV, $8 \mu \mathrm{l}$ of DNA was used in a reaction volume of $25 \mu$ l.

\section{RARE Mapping}

RARE cleavage was used to map different BAC clones. The protocol described above was used but was scaled down to $25 \%$ and only $1 \mu \mathrm{g}$ of BAC DNA was used.

\section{Lambda Terminase Cleavage}

BAC DNA $(1 \mu \mathrm{g})$ was digested with 10 units of lambda terminase (Promega) in a total volume of $25 \mu \mathrm{l}$ for $2 \mathrm{hr}$ at $30^{\circ} \mathrm{C}$ as recommended by the manufacturer. The efficiency was close to $100 \%$ when lambda terminase from Promega was used.

\section{Sequencing of $\mathrm{Pl}$ and $\mathrm{BAC}$ DNA}

Sequencing was performed with $3.25 \mu \mathrm{g}$ of DNA, $16 \mu \mathrm{l}$ of ABI PRISM Dye Terminator Cycle Sequencing Ready Reaction Kit with AmpliTaq DNA Polymerase, FS (Perkin Elmer), and 6.4 pmole of primer in a total reaction volume of $40 \mu \mathrm{l}$. The oligonucleotides ( 25 -mers) were designed by the Oligo Primer Analysis Software program, version 5.0 (NBI). Cycle sequencing was performed on the GeneAmp PCR System 9600 (Perkin Elmer) at a denaturation temperature of $96^{\circ} \mathrm{C}(5 \mathrm{~min})$, followed by 25 polymerase chain reaction (PCR) cycles $\left(10 \mathrm{sec}\right.$ at $96^{\circ} \mathrm{C}, 5 \mathrm{sec}$ at $50^{\circ} \mathrm{C}$, and 5 $\min$ at $62^{\circ} \mathrm{C}$ ). Unincorporated dye terminators were removed from reaction mixtures by precipitation with ethanol. Gel electrophoresis and automatic data collection were performed with ABI 373A DNA sequencers (Perkin Elmer).

\section{ACKNOWLEDGMENTS}

J. Borén is supported by the Howard Hughes Medical Institute with a Howard Hughes Postdoctoral Fellowship for Physicians. This work also was supported by National Heart, Lung, and Blood Institute grant HL-47660. The authors thank S. Ordway and G. Howard for editorial assistance, J. Carrol and B. Clark for help in preparing the figures, and A. Corder and S. Gonzales for photographic work.

The publication costs of this article were defrayed in part by payment of page charges. This article must therefore be hereby marked "advertisement" in accordance with 18 USC section 1734 solely to indicate this fact.

\section{REFERENCES}

Callow, M.J. and E.M. Rubin. 1995. Site-specific mutagenesis demonstrates that cysteine 4326 of apolipoprotein B is required for covalent linkage with apolipoprotein(a) in vivo. J. Biol. Chem.

270: 23914-23917.

Callow, M.J., L.J. Ferrin, and E.M. Rubin. 1994. Single base, site-directed mutagenesis of a 90-kilobase-pair P1 clone. Nucleic Acids Res. 22: 4348-4349.

Ferrin, L.J. 1995. Manipulating and mapping DNA with RecA-assisted restriction endonuclease (RARE) cleavage. Genet. Eng. (NY) 17: 21-30.

Ferrin, L.J. and R.D. Camerini-Otero. 1991. Selective cleavage of human DNA: RecA-assisted restriction endonuclease (RARE) cleavage. Science 254: 1494-1497.

Linton, M.F., R.V. Farese Jr., G. Chiesa, D.S. Grass, P. Chin, R.E. Hammer, H.H. Hobbs, and S.G. Young. 1993. Transgenic mice expressing high plasma concentrations of human apolipoprotein B100 and lipoprotein(a). J. Clin. Invest. 92: 3029-3037.

McCormick, S.P.A., M.F. Linton, and S.G. Young. 1994. Expression of P1 DNA in mammalian cells and transgenic mice. Genet. Anal. Tech. Appl. 11: 158-164.

McCormick, S.P.A., J.K. Ng, S. Taylor, L.M. Flynn, R.E. Hammer, and S.G Young. 1995. Mutagenesis of the human apolipoprotein $B$ gene in a yeast artificial chromosome reveals the site of attachment for apolipoprotein(a). Proc. Natl. Acad. Sci. 92: 10147-10151.

McCormick, S.P.A., K.R. Peterson, R.E. Hammer, C.H. Clegg, and S.G. Young. 1996. Generation of transgenic mice from yeast artificial chromosome DNA that has been modified by gene targeting. Trends Cardiovasc. Med. 6: $16-24$.

Peterson, K.R., Q.-L. Li, C.H. Clegg, T. Furukawa, P.A. Navas, E.J. Norton, T.G. Kimbrough, and G. Stamatoyannopoulos. 1995. Use of yeast artificial chromosomes (YACs) in studies of mammalian development: Production of b-globin locus YAC mice carrying human globin developmental mutants. Proc. Natl. Acad. Sci. 92: 5655-5659.

Shizuya, H., B. Birren, U.J. Kim, V. Mancino, T. Slepak, Y. Tachiiri, and M. Simon. 1992. Cloning and stable maintenance of 300-kilobase-pair fragments of human DNA in Escherichia coli using an F-factor-based vector. Proc. Natl. Acad. Sci. 89: 8794-8797.

Van Leuven, F., L. Stas, C. Hilliker, K. Lorent, L. Umans, L. Serneels, L. Overbergh, S. Torrekens, D. Moechars, B. De Strooper, and H. Van Den Berghe. 1994. Structure of the gene (LRP1) coding for the human alpha 2-macroglobulin receptor lipoprotein receptor-related protein. Genomics 24: 78-89.

Received June 27, 1996; accepted in revised form August 30, 1996. 


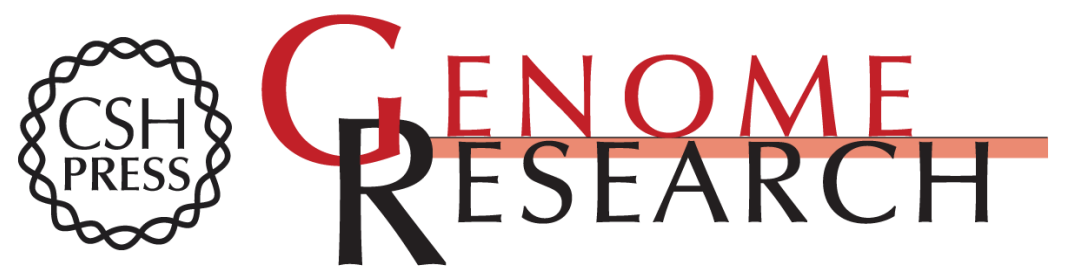

\section{A simple and efficient method for making site-directed mutants, deletions, and fusions of large DNA such as P1 and BAC clones.}

J Borén, I Lee, M J Callow, et al.

Genome Res. 1996 6: 1123-1130

Access the most recent version at doi:10.1101/gr.6.11.1123

References This article cites 11 articles, 5 of which can be accessed free at:

http://genome.cshlp.org/content/6/11/1123.full.html\#ref-list-1

\section{License}

Email Alerting Receive free email alerts when new articles cite this article - sign up in the box at the Service top right corner of the article or click here.

\section{Affordable, Accurate Sequencing.}

